\title{
Two Vibrio splendidus related strains collaborate to kill Crassostrea gigas: taxonomy and host alterations
}

\author{
Mélanie Gay ${ }^{1}$, Tristan Renault ${ }^{1}$, Anne-Marie Pons ${ }^{2}$, Frédérique Le Roux ${ }^{1, *}$ \\ ${ }^{1}$ Laboratoire de Génétique et Pathologie, Institut Français de Recherche pour l'Exploitation de la Mer (IFREMER), \\ 17390 La Tremblade, France \\ ${ }^{2}$ Laboratoire de Biotechnologie et Chimie Bio-Organique, CNRS FRE 2766, Université La Rochelle, Pôle Sciences, \\ 17042 La Rochelle Cedex, France
}

\begin{abstract}
For several years, strains phenotypically related to Vibrio splendidus have been associated with mortality outbreaks of molluscs. A former study on Crassostrea gigas demonstrated the genetic diversity of $V$. splendidus strains associated with diseased animals. Another study suggested that different strains may act in an additive/synergistic way leading to higher C. gigas mortality rates. Here, a strain pair $(31+32)$ was characterised at taxonomic and virulence levels. Using a polyphasic approach, these strains were confirmed to be $V$. splendidus-related, without a clear discrimination between $V$. kanaloae and $V$. pomeroyi since hybridisation rates with both these strains were above $70 \%$. Following experimental infection of $C$. gigas by injection in the adductor muscle or in the pallial cavity, the host alterations induced were described. After injection of strains 31 and/or 32, bacteria were localised at the periphery of the muscle and induced extensive lesions of the translucent part of the adductor muscle. Muscle alterations were of 3 kinds: (1) presence of isolated rounded muscular fibres containing non-homogenous granular material and surrounded by a translucent halo; (2) presence of non-homogenous granular material in the cytoplasm of entire muscle bands; (3) affection of wide muscle areas with extremely condensed muscle fibres. Infiltration associated with these lesions was notably absent in the vast majority of the individuals.
\end{abstract}

KEY WORDS: Vibriosis · Agonism · Molecular taxonomy $\cdot$ Histopathology

\section{INTRODUCTION}

Vibrio splendidus (Baumann et al. 1980, Baumann \& Schubert 1984) is widely distributed in marine ecosystems (Nealson et al. 1993, Farto et al. 1999). It has long been considered an environmental organism with no pathogenic significance (Baticados et al. 1990, Paillard \& Maes 1990, Myhr et al. 1991, Castro et al. 1992). However, for several years, different strains phenotypically related to this species have been associated with mortalities of molluscs, including Pecten maximus (Nicolas et al. 1996), Crassostrea gigas (Sugumar et al. 1998, Lacoste et al. 2001, Waechter et al. 2002) and Octopus vulgaris (Farto et al. 2003), and fish, Scophthalmus maximus (Gatesoupe et al. 1999). The present controversial status of $V$. splendidus (pathogenic/ opportunistic) seems to be due to a lack of pertinent diagnostic tools for its identification and for the evaluation of its potential pathogenic capacity.

Epidemiological studies of Vibrio splendidus strains associated with mollusc mortality outbreaks have demonstrated the genetic diversity within this group and suggested its polyphyletic nature (Le Roux et al. 2002, 2004). At least 4 species, V. lentus, V. kanaloae, V. pomeroyi and $V$. chagasii, phenotypically related to $V$. splendidus have been described on a molecular basis (gyrase B subunit, gyrB, and 16S rRNA sequences, and Amplified Fragment Length Polymorphisms), although no biochemical method is available to clearly discriminate species within this group (Macian et al. 2001, 
Thompson et al. 2003a,b). Therefore, taxonomic identification of $V$. splendidus related strains should be conducted using a polyphasic approach employing new phenotypic tests and molecular techniques (Thompson et al. 2001, Stackenbrandt et al. 2002, Le Roux et al. 2004).

A wide range of virulence among strains related to Vibrio splendidus has been observed by experimental exposure on different animal models (Sugumar et al. 1998, Farto et al. 1999, Gatesoupe et al. 1999, Le Roux et al. 2002, Gay et al. 2004). Studies of ribosomal and gyrB gene polymorphisms or RAPD have not led to the identification of markers associated with pathogenicity. Thus, so far, there is no phenotypic or genotypic feature to distinguish pathogenic from non-pathogenic strains, and the only way to determine the virulence of a given strain remains experimental infection. However, results may vary from one trial to another. The development of cellular and/or molecular tests to evaluate the potential virulence of strains is necessary. The development of such bioassays requires preliminary descriptions of host alterations to define the virulence mechanisms implicated in the pathogenesis.

Although Vibrio splendidus-related strains have been associated with outbreaks of mortality among several aquatic animals, pathogenesis has not yet been well defined. Martin et al. (2002) described some V. splendidus strains inducing tissue necrosis and mass mortality in gorgons (Paramuricea clavata, Eunicella cavolinii and E. singularis). A V. lentus strain, isolated from diseased octopus (Octopus vulgaris), is able to induce round, hard lesions in the arm or head mantle (Farto et al. 2003). However, so far, there has been no histological description following experimental or natural exposure of bivalves to $V$. splendidus related strains.

In a former study, a collection of Vibrio strains isolated from Crassostrea gigas, genotyped by gyrBbased phylogenetic analysis and screened for their virulence by experimental infection, was established (Gay et al. 2004). Few strains displayed an individual pathogenicity; however, quite an important number of strains displayed an enhanced virulence when concomitantly inoculated, suggesting an agonistic action. In particular, this collaboration has been shown to be statistically significant for the strains 31 and 32. These 2 strains appear closely related but may each possess a specific virulence feature, which, when simultaneously expressed, leads to an increased pathogenicity.

In the present study, these strains were taxonomically characterised using a polyphasic approach (16S and gyrB gene sequence analysis, DNA/DNA hybridisation, and numerical taxonomy). Light and transmission electron microscopy examination was carried out on oysters following different inoculation methods (intrapallial or intramuscular injection) of the strains 31 and/or 32 to describe common and specific tissular alterations.

\section{MATERIALS AND METHODS}

Bacterial strains. The strains used in this study were either isolated from haemolymph of oysters suffering from summer mortality outbreaks $(31,32,47)$ (Gay et al. 2004) or purchased from national collections (CIP: Collection de l'Institut Pasteur, Paris, France; LMG: Laboratorium voor Mikrobiologie, Universiteit Gent, Belgium). Strains are maintained at the European Community Reference Laboratory for Molluscs Diseases as part of the collection (Centre de Ressources Biologiques, Laboratoire de Génétique et Pathologie, IFREMER, La Tremblade, France).

Phenotypic characterisation. Phenotypic profiles of strains and numerical taxonomy were determined from 80 classical biochemical tests as described in Le Roux et al. (2004). The following reference strains were included in the numerical analysis: Vibrio splendidus

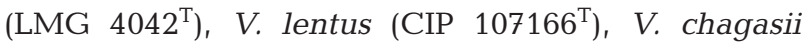
(TNEMF6), V. aestuarianus (01/32), V. mediterranei (CIP 103203 ${ }^{\mathrm{T}}$ ), V. campbellii (CIP 7067), V. alginolyticus (LMG 4409), V. harveyi (CIP 105197), V. pelagius LMG $3897^{\mathrm{T}}$ ), V. fluvialis (CIP $103355^{\mathrm{T}}$ ), V. natriegens (LMG 10935 $5^{\mathrm{T}}$ ).

Phylogenetic analyses. DNA extraction, 16S rDNA and DNA gyrase subunit $(g y r B)$ amplification and sequencing were performed using primers and methods previously described (Le Roux et al. 2004). Sequences were aligned and phylogenetic analyses were performed using Seaview and Phylo-win programs (Galtier et al. 1996). Phylogenetic trees were built using the BIONJ method (Gascuel 1997) applied to Kimura's 2-parameter distances. Reliability of topologies was assessed by the bootstrap method with 1000 replicates.

Quantitative DNA-DNA hybridisation. Labelling of DNA probes with tritium-labelled nucleotides was performed by the random primed method (Megaprime labelling kit, Amersham) and hybridisation was carried out at $60^{\circ} \mathrm{C}$ by the S1-nuclease method (Crosa et al. 1973, Grimont et al. 1980) with adsorption of S1-resistant onto DE81 filters (Whatman).

Experimental infection. Bacteria were grown at $20^{\circ} \mathrm{C}$ for $36 \mathrm{~h}$ in marine broth (Diagnostic Pasteur) and harvested in autoclaved $\left(121^{\circ} \mathrm{C}\right.$ for $\left.15 \mathrm{~min}\right)$ seawater at a concentration of $8 \times 10^{8} \mathrm{CFU} \mathrm{m}^{-1}$ evaluated by spectrophotometer (Eppendorf) at $600 \mathrm{~nm}$. This bacterial concentration was accurately determined by enumeration on marine agar plates using a conventional dilution plating technique with incubation at $20^{\circ} \mathrm{C}$ for $2 \mathrm{~d}$ (not shown).

Intrapallial injection: Oyster spat originated from natural beds, measured 4 to $6 \mathrm{~cm}$ and were 12 to $18 \mathrm{mo}$ old. The shell was filed away on the dorsal side to form a gap between the valves. The conditions tested were 
strains 31,32 or $31+32$ in triplicate. A volume of $50 \mu \mathrm{l}$ of the bacterial suspension (i.e. $4 \times 10^{7} \mathrm{CFU}$ ) was injected into the pallial cavity. Negative controls consisted of groups of 30 oysters injected with sterile seawater (SSW). After injection, oysters were held out of water overnight at $20^{\circ} \mathrm{C}$. They were then transferred to aquaria (30 oysters per $2.5 \mathrm{l}$ aquarium) containing aerated $5 \mu \mathrm{m}$-filtered seawater at $20^{\circ} \mathrm{C}$, kept under static conditions and fed daily with a mixture of Isochrisis galbana and Chaetoceros calcitrans. Mortality was recorded daily. The water was changed once a week.

Bath exposure: The oyster spat used originated from the IFREMER nursery (La Tremblade, France), measured 1 to $2 \mathrm{~cm}$ and were 4 mo old. The conditions tested SSW, strain 47 (strain of lower virulence and phylogenetically related to Vibrio splendidus), 31, 32 or $31+32$ in triplicate. One hundred juvenile oysters were kept overnight in $400 \mathrm{ml}$ of bacterial suspension $\left(10^{7} \mathrm{CFU} \mathrm{\textrm {ml } ^ { - 1 }}\right)$ in aerated $5 \mu \mathrm{m}$-filtered seawater supplemented with a mixture of Isochrisis galbana and Chaetoceros calcitrans. Two litres of $5 \mu \mathrm{m}$-filtered seawater were then added per aquarium. Oysters were kept as described above. The water was changed once a week.

Intramuscular injection: Oysters were intramuscularly injected with bacterial strains as described by Gay et al. (2004). Conditions were SSW, 47, 31, 32 and $31+32$.

Histology and electron microscopic examination. As soon as mortality was observed in the individuals experimentally challenged by injection in the adductor muscle, moribund and live oysters in all conditions were fixed in Davidson's or Carson's fixative (Renault \& Cochennec 1995). For oysters injected in the pallial cavity, individuals were fixed in Davidson's fixative as soon as they displayed a weakness of the adductor muscle. Individuals in Davidson's fixative were prepared according to Renault \& Cochennec (1995). Slides were stained with haematoxylin and eosin. Slides were examined on an Olympus BX50 optical microscope.

Small pieces of tissue ( 3 to $4 \mathrm{~mm}$ ) from individuals fixed in Carson's fixative were processed for transmission electron microscopy according to Renault \& Cochennec (1995). Ultrathin sections were then examined in a JEOL JEM 1200EX electron microscope at $80 \mathrm{kV}$.

\section{RESULTS}

\section{Taxonomic characterisation}

Following phenotypic analysis and numerical taxonomy, based on 80 biochemical tests, strains 31 and 32 displayed more than $80 \%$ similarity with type strains belonging to Vibrio splendidus polyphyletic group i.e. $V$. kanaloae, V. pomeroyi, V. tasmaniensis, V. lentus, $V$. chagasii and $V$. splendidus. Table 1 sums up the discriminant tests between strains 31 and 32 and the $V$. splendidus-related type strains.

Table 1. Biochemical characteristics of 31, 32 and type strains belonging to Vibrio splendidus polyphyletic group. Only the 20 discriminant tests are given

\begin{tabular}{|c|c|c|c|c|c|c|c|c|}
\hline & 31 & 32 & 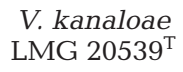 & $\begin{array}{l}\text { V. tasmaniensis } \\
\text { LMG20012 }^{\mathrm{T}}\end{array}$ & $\begin{array}{l}V . \text { pomeroyi } \\
\text { LMG20537 }^{\mathrm{T}}\end{array}$ & $\begin{array}{l}\text { V. chagasii } \\
\text { LMG } 21353^{\mathrm{T}}\end{array}$ & $\begin{array}{l}\text { V. splendidus } \\
\text { LMG } 4042^{\mathrm{T}}\end{array}$ & $\begin{array}{c}\text { V. lentus } \\
\text { CIP } 107166^{\mathrm{T}}\end{array}$ \\
\hline $\mathrm{ADH}$ & + & + & + & - & + & + & - & - \\
\hline$\beta$-galactosidase & - & - & + & - & + & - & + & + \\
\hline $\mathrm{NO}_{2}$ production & - & + & - & + & - & - & - & - \\
\hline Gelatinase & - & + & + & - & + & + & + & + \\
\hline Catalase & + & + & + & + & + & - & + & + \\
\hline TDA & - & - & + & - & + & + & - & - \\
\hline \multicolumn{9}{|l|}{ Acid from } \\
\hline Mannitol & + & - & + & + & + & + & + & + \\
\hline Saccharose & + & - & + & - & - & + & - & - \\
\hline Melibiose & - & - & - & - & - & - & + & - \\
\hline Amygdaline & + & + & + & - & + & - & + & - \\
\hline Glycerol & + & + & + & - & - & - & + & - \\
\hline Galactose & - & - & + & - & + & - & + & - \\
\hline Esculine & - & + & + & + & + & + & + & - \\
\hline Mannose & + & + & + & + & + & - & + & + \\
\hline Glycogene & + & + & + & - & + & + & + & + \\
\hline Amidon & + & + & + & - & + & + & + & - \\
\hline \multicolumn{9}{|l|}{ Growth } \\
\hline $4^{\circ} \mathrm{C}$ & + & + & + & - & + & - & + & - \\
\hline $35^{\circ} \mathrm{C}$ & - & - & + & - & - & - & + & - \\
\hline $40^{\circ} \mathrm{C}$ & - & - & + & - & - & - & - & - \\
\hline $6 \% \mathrm{NaCl}$ & - & - & + & + & + & + & - & - \\
\hline
\end{tabular}


Phylogenetic analysis of Vibrio splendidus related strains was carried out by comparison of the nucleotide sequences (1200 bp) of the small subunit ribosomal RNA genes (16S rDNA, Fig. 1) and gyrase B subunit $($ gyrB) genes. In the 16S rDNA tree, clustering of strain 31, 32 and $V$. lentus, V. splendidus, V. tasmaniensis type strains was supported by a bootstrap value of $95 \%$. In the gyrB tree, the same clustering as formerly described (Gay et al. 2004) was obtained despite a longer sequence analysed (1200 bp instead of 588). Strain 32 was separated from a cluster containing strain 31, V. kanaloae, V. tasmaniensis and $V$. pomeroyi type strains with a bootstrap value of $100 \%$.

DNA-DNA hybridisation was performed with DNA of strains 31, 32, LMG 20539 ${ }^{\mathrm{T}}$ ( $V$. kanaloae), LMG $20537^{\mathrm{T}}$ ( $V$. pomeroyi), CIP $107166^{\mathrm{T}}$ ( $V$. lentus), LMG $4042^{\mathrm{T}}$ ( $V$. splendidus), LMG $21359^{\mathrm{T}}$ ( $V$. cyclitrophicus) as targets and 31 or 32 DNA as probes (Table 2). Rates of hybridisation ranged between $40 \%$ (31 - V. cyclitrophicus) and 92\% (31-V. kanaloae). Both strain 31 and strain 32 probes hybridised at more than $70 \%$ with $V$. kanaloae (92 and $87 \%$, respectively) and with $V$. pomeroyi (72 and $76 \%$, respectively).

\section{Experimental infection}

Intrapallial injection. When strains were injected in the pallial cavity, mortality began $7 \mathrm{~d}$ post injection. The mean highest mortality rate at $21 \mathrm{~d}$ post injection was induced by $31+32$ (36\%), followed by $31(29.5 \%)$, then $32(19.2 \%)$ and SSW (18.6\%).

Bath exposure. At 30 d post exposure to SSW, suspensions of $47,31,32$ or $31+32$, no mortality had occurred.

\section{Histology and electron microscopy examination}

Oysters were histologically analysed after injection of SSW, strain $47,31,32$, or $31+32$ in the adductor muscle (Gay et al. 2004) or after injection of SSW, 31, 32 , or $31+32$ in the pallial cavity. After the injection in the adductor muscle, some live oysters were sampled as soon as mortality began i.e. $24 \mathrm{~h}$. Beginning at $1 \mathrm{wk}$ after the injection in the pallial cavity, oysters showing signs of weakness of the adductor muscle were sampled daily. For both types of inoculation, bacterial localisations and induced alterations were similar.

Bacterial localisation. Oysters injected with 47 showed scarce bacteria in the adductor muscle; these were located between the muscular fibres. In oysters injected with 31,32 , or $31+32$, bacteria were localised in foci either between muscular fibres at the periphery of the adductor muscle (Fig. 2a) or in the connective

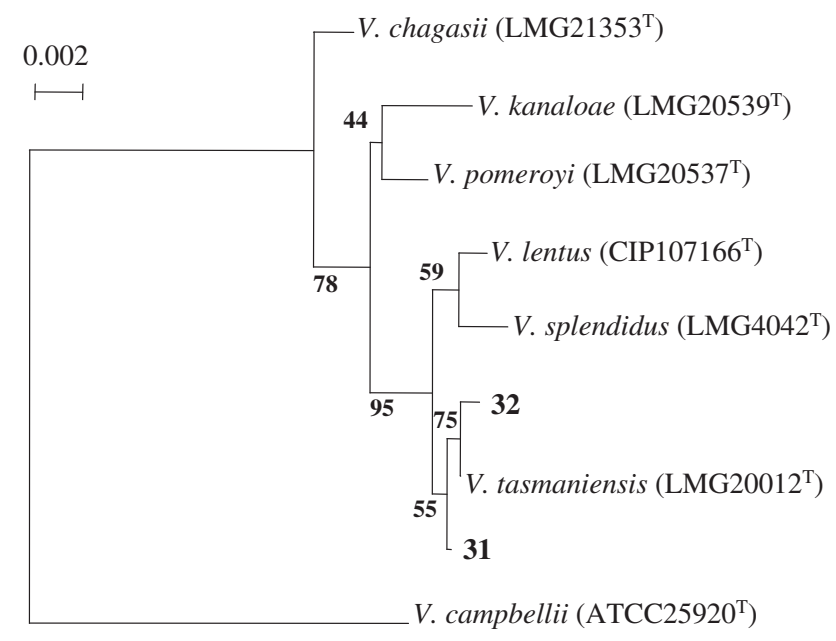

Fig. 1. Phylogenetic tree of partial 16S rDNA. The Vibrio campbellii homologue was used as outgroup. 1200 gap-free sites were compared. Horizontal branch lengths are proportional to evolutionary divergence. Bootstrap values (percent of 1000 replicates) appear next to the corresponding branch

tissue surrounding this organ (Fig. 2b). Some foci were also observed in the kidney close to the injected muscle, whereas no foci were observed in mantle, gills, or digestive gland. Transmission electron microscopy of pieces of the adductor muscle led to the observation of bacterial foci in the connective tissue between muscular fibres (Fig. 3).

Tissular and cellular alterations. After injection of SSW (Fig. 4a) or 47, all the organs appeared unaltered, except in the case of a few individuals injected with 47 , which showed slight and localised alterations of the adductor muscle.

Following the injection of 31 and/or 32, the most altered organ was the translucent part of the adductor muscle, whereas the crescent shaped white part did not generally display any lesion. The other organs were undamaged, except for some individuals displaying localised infiltration in the gills and connective tissues.

Table 2. Intraspecific DNA-DNA homology among strains 31 and 32 and type strain belonging to Vibrio splendidus polyphyletic group. Numbers in bold represent hybridisation rates over $70 \%$

\begin{tabular}{|lrr|}
\hline & 31 & 32 \\
\hline 31 & 100 & 81 \\
32 & 79 & 100 \\
V. kanaloae (LMG 20539 ${ }^{\mathrm{T}}$ ) & $\mathbf{9 2}$ & $\mathbf{8 7}$ \\
V. pomeroyi (LMG 20537 $)$ & $\mathbf{7 2}$ & $\mathbf{7 6}$ \\
V. lentus (CIP 107166 ${ }^{\mathrm{T}}$ ) & 64 & 63 \\
V. splendidus (LMG 4042 ${ }^{\mathrm{T}}$ ) & 56 & 62 \\
V. cyclitrophicus (LMG 21359 ${ }^{\mathrm{T}}$ ) & 40 & 53 \\
\hline
\end{tabular}



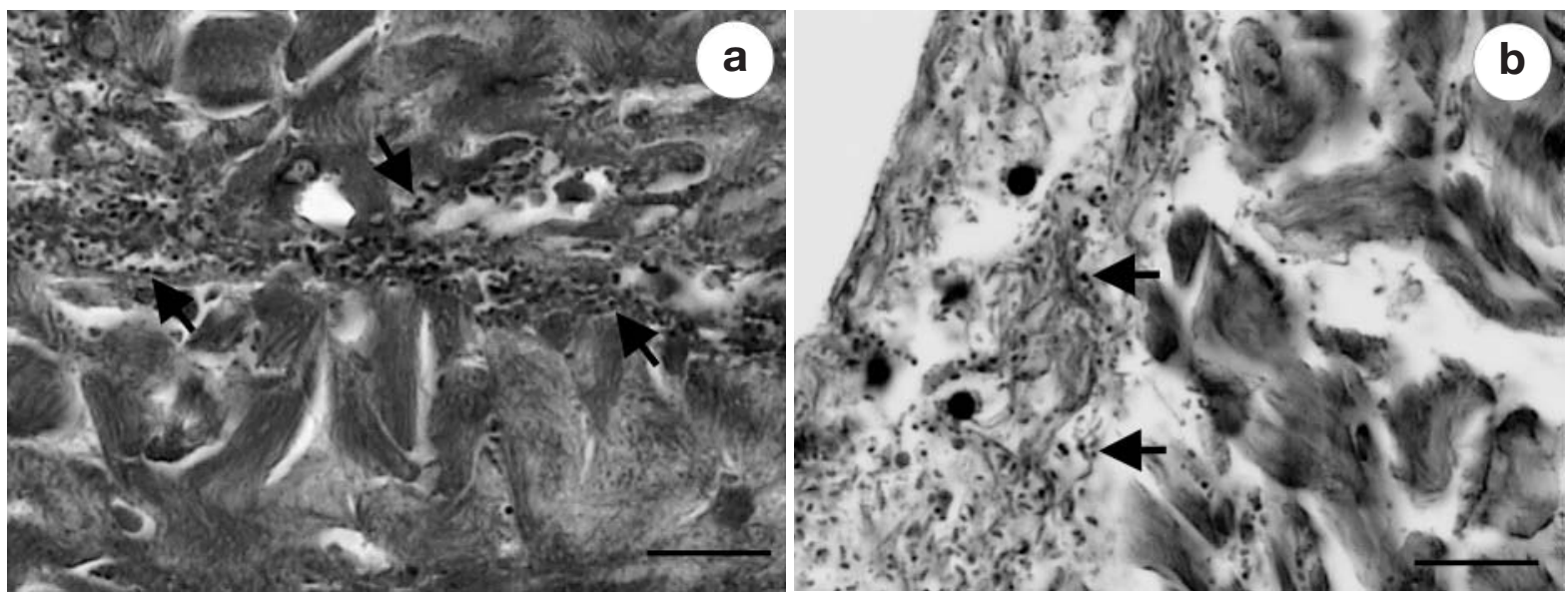

Fig. 2. Crassostrea gigas. Localisation of the bacteria (arrows) after experimental infection by injection in the adductor muscle. (a) Between muscular fibres at the periphery of the adductor muscle, (b) in the connective tissue surrounding the adductor muscle. HE staining, scale bars $=10 \mu \mathrm{m}$

Muscle of individuals injected with SSW displayed a homogeneous structure where muscle fibres formed dense bands surrounded by connective tissue (Fig. 4a). In cross sections, bands appeared as separate packed units (Fig. 4a). Haemocytes were usually present between the fibres and in the connective tissue. Muscle fibres were long cylindrical cells including an oval shaped nucleus near the cell surface, and a homogenous cytoplasm. In individuals injected with strains 31 and/or 32 , the translucent part of the adductor muscle displayed several kinds of lesions (Fig. 4b-d). The first type of alteration was characterised by the presence of peculiar muscle cells, arbitrarily distributed throughout the organ. These cells were oval or round and contained nonhomogenous granular material surrounded by a translucent halo (Fig. 4b). These structures were interpreted as degenerating cells. The second type of alteration affected entire muscle bands. Granular and nonhomogenous material was observed in the muscle cells as in the first type of alteration. Most of the damaged cells were of an unmodified shape, except for a few round cells, as in the first kind of alteration (Fig. 4c). Whole damaged muscle bands displayed a general swelling of the cells (rounded or not) as observed when Fig. 4b,c were compared. This type of lesion was more extensive than before but still quite localised. The third type of alteration usually affected wide muscle areas. Muscle fibres appeared extremely condensed resulting in large clear gaps (Fig. 4d).

Even though some cells appeared as degenerating, these 3 types of lesions were not associated with any noticeable infiltration of haemocytes (Fig. 4b-d). Nevertheless, rare individuals displayed massive infiltrations where large areas of the adductor muscle were infiltrated by haemocytes with some condensed muscular fibres in between (Fig. 5).
Transmission electron microscopy (Fig. 6) confirmed the lesions observed in light microscopy. Healthy and damaged muscular fibres were seemingly arbitrarily distributed throughout the adductor muscle. Whereas the cytoplasmic content of these damaged cells was severely degenerating, an apparently intact cytoplas-

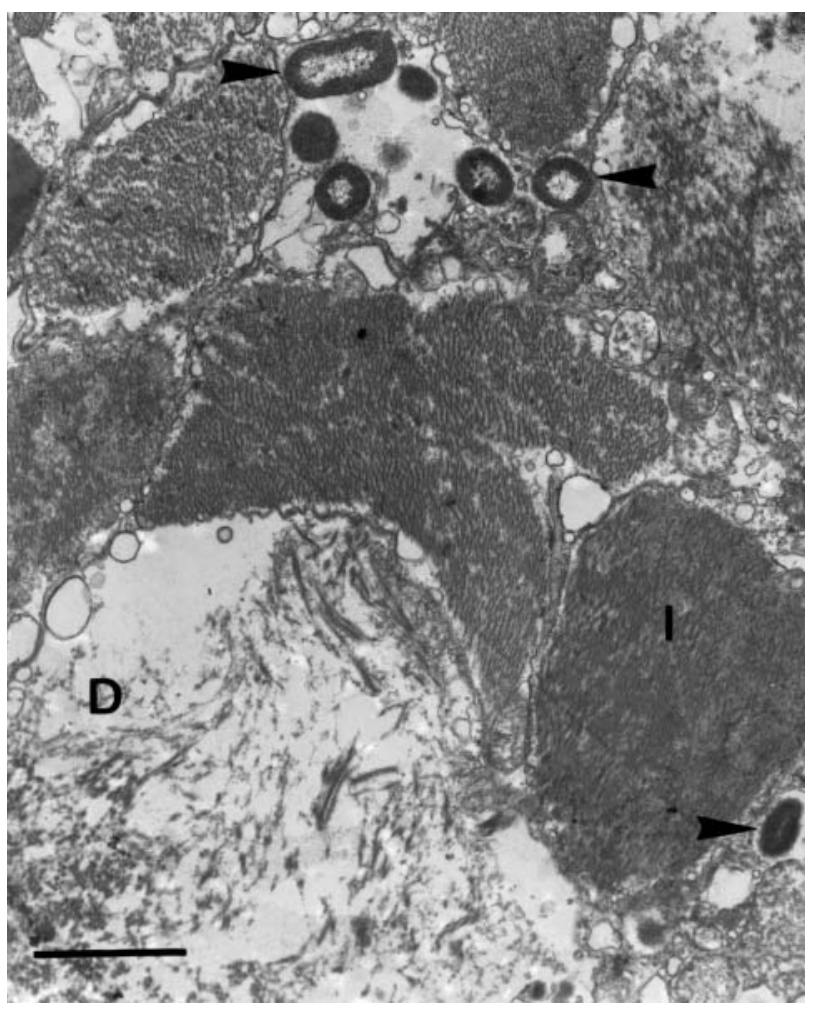

Fig. 3. Crassostrea gigas. Localisation of the bacteria (arrowheads) after experimental infection by injection in the adductor muscle. I: intact muscle fibres, D: degenerating muscle fibres. TEM, scale bar $=2 \mu \mathrm{m}$ 


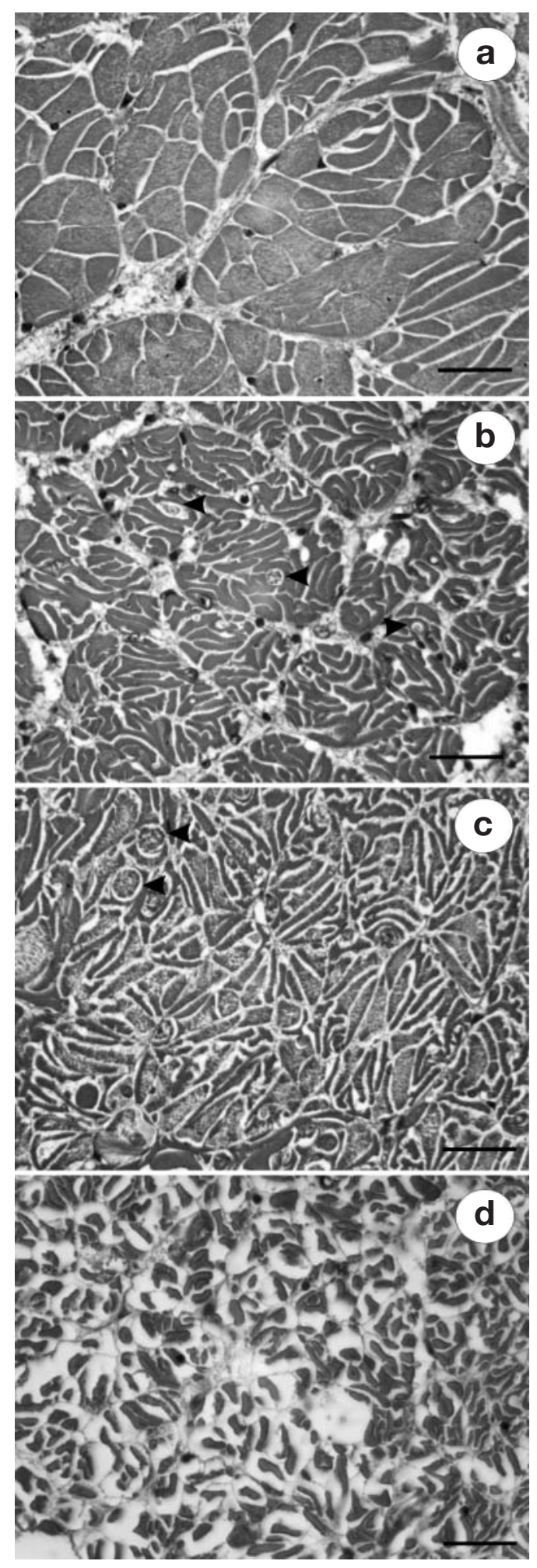

Fig. 4. Crassostrea gigas. Adductor muscle following the injection of (a) sterile seawater, (b-d) 31+32 into the adductor muscle. (b) Granular and non-homogenous round structures (arrowheads); (c) entire muscle bands altered with some rounded cells (arrowheads); (d) condensed muscle fibres and clear gaps in between. HE staining, scale bars $=20 \mu \mathrm{m}$

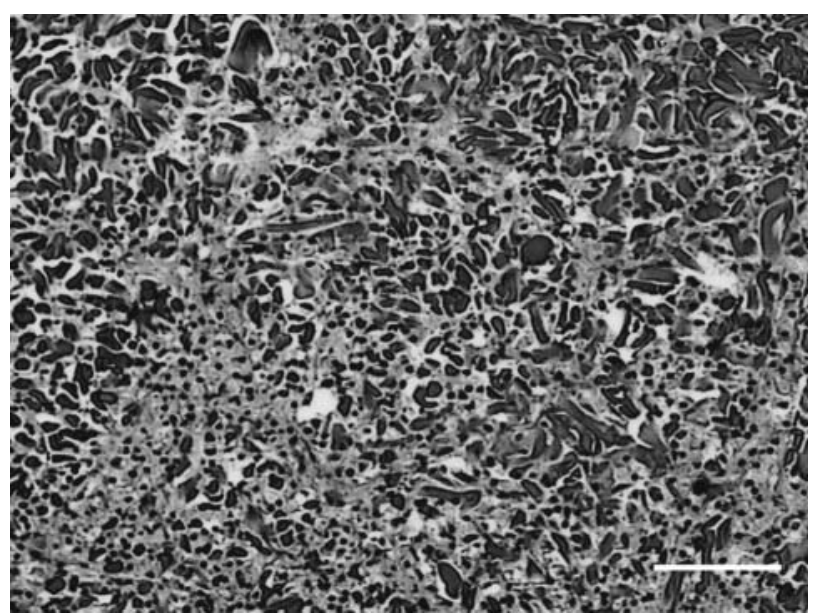

Fig. 5. Crassostrea gigas. Intense infiltration following injection in the adductor muscle. HE staining, scale bar $=50 \mu \mathrm{m}$

mic membrane was observed surrounding these structures, which could be interpreted as the endomysium (Fig. 6). Some apparently intact mitochondria and clear vacuoles were also observed within these degenerating cells (not shown). The myofibril density decrease induced by the degeneration of myofibrils observed in transmission electron microscopy could be the counterpart of the granular structures of the first and second types of alteration observed in light microscopy.

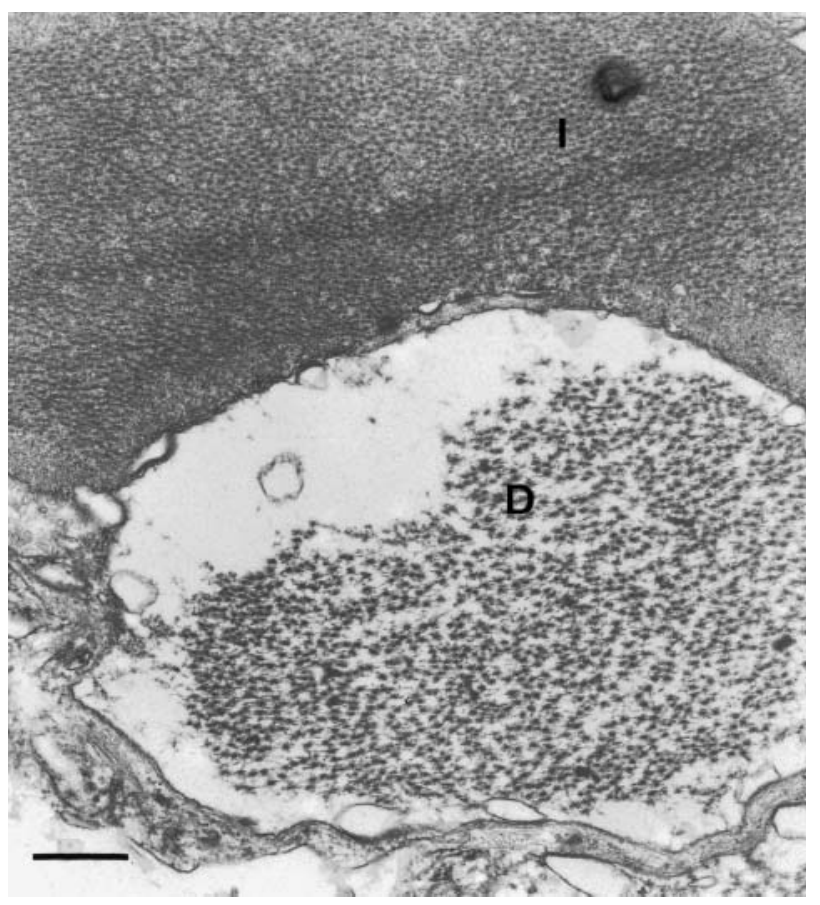

Fig. 6. Crassostrea gigas. Myofibril alterations following the injection of $31+32$ into the adductor muscle. I: intact muscle fibres, D: degenerating muscle fibres. TEM, scale bar $=500 \mathrm{~nm}$ 


\section{DISCUSSION}

In a former study (Gay et al. 2004), strains 31 and 32 were selected as a model because they were related to Vibrio splendidus, a group previously associated with several mollusc and fish mortality events. They illustrate the collaborative effect observed for different strains that will allow us to analyse the shared and/or different mechanisms of virulence implicated in this agonistic action.

The relationships between strains 31 and 32 and the other Vibrio splendidus related new species were evaluated using a polyphasic approach. Neither classical biochemical tests nor phylogenetic study based on 16S rDNA or gyrB led to a clusterisation of these strains with a unique species. DNA-DNA hybridisation recognised as the reference method for bacterial systematics (Grimont 1984), led us to define 31 and 32 as belonging to the polyphyletic group $V$. splendidus without clear discrimination between $V$. kanaloae and $V$. pomeroyi. These results could be due either to a lack of discriminatory power of the molecular methods used or to an intermediate position of our strains between the 2 species. Experiments are in progress to develop new phylogenetic analyses using a multilocus scheme.

Putative pathogenic bacteria for Crassostrea gigas had been selected by injection of bacterial suspension in the adductor muscle (Lacoste et al. 2001, Le Roux et al. 2002). The results are obtained quickly using this technique since mortality appears as soon as $24 \mathrm{~h}$ post injection; however, drawbacks, such as disruption of tissues and variability, were observed. Less invasive methods were tested and the mortality induced was described. The injection in the pallial cavity is an alternative since it allows the transmission of the disease without disrupting the tissues. However, this method does not accurately reflect natural infection due to the artificial crossing of the mechanical barrier (shell and mantle) and the stress induced by a long period of time under static conditions. This method did, however, confirm the collaboration between 31 and 32, and histopathology demonstrated that bacteria localisation and induced lesions were similar following intrapallial or intramuscular inoculation.

Bath exposure did not induce any mortality. However, this is quite often encountered among pathogens of aquatic animals. Li et al. (1998) failed to infect abalone Haliotis discus hannai Ino with virulent Vibrio fluvialis by bath exposure, whereas abalone infected through foot lesions developed the bacterial disease. Experimental infection of Atlantic salmon Salmo salar by $V$. salmonicida and Aeromonas salmonicida led to higher reproducible results following intraperitoneal injection compared to cohabitation or bath exposure (Nordmo \& Ramstad 1999). Since bath exposure of
Crassostrea gigas with $V$. splendidus did not lead to any mortality, Lacoste et al. (2001) suggested that $V$. splendidus was transmitted vertically; however, other hypotheses may be proposed for these negative results and for the variability sometimes observed in the different inoculation methods. First, as for the bacteria, culture media or environmental conditions may modulate the expression of virulence factors (Ottaviani et al. 2001), or subcultures may lead to a loss of virulence. Second, as for the oyster, animals may have suffered mortality or stress prior to the experimental infection, or a particular status of the host (genetic and/or physiologic) may be necessary for initiation of pathogenesis and/or susceptibility of the host. For instance, maturation may induce an increased susceptibility to infection. This hypothesis is supported by the knowledge that the gametogenesis is a period of negative energy budget (Soletchnik et al. 1997) where most of the acquired energy is used for the production of gametes to the detriment of the defence mechanisms (Perdue et al. 1981, Myrand et al. 2000). Experiments are in progress to evaluate the role of environmental and host factors in the pathogenesis of disease due to $V$. splendidus related strains.

Host alterations following experimental infection after bacterial inoculation are reported. The only macroscopic sign preceding oyster death was a weakness of the adductor muscle. No alteration or organic deposit was observed on the shell of infected animals, although such macroscopic signs have been previously described following Vibrio splendidus infection (Lambert et al. 1999). In oysters injected with 47 , few bacteria were observed, suggesting that this strain had been cleared shortly after the injection in contrast to 31 and/or 32 (Kelly \& Dinuzzo 1985, Lopez-Cortes et al. 1999). In oysters injected with 31,32 or $31+32$, bacteria were always localised either between muscular fibres at the periphery of the adductor muscle or in the connective tissue surrounding this organ or in the part of the kidney running along the adductor muscle. However, the whole adductor muscle was severely damaged, which is in contrast with the localisation of bacteria only at the periphery of this organ. Based on the literature, several hypotheses may be suggested. Bacteria may produce toxins without the bacteria themselves being present at the altered site. In the withering syndrome of abalone, Rickettsiales-like prokaryotes are localised in gastrointestinal epithelium cells and induce digestive gland degeneration and foot muscle atrophy (Moore et al. 2001, Friedman et al. 2002). Bacterial density may be too low to be detected. In borreliosis, few spirochetes are observed in tissues (Cadavid et al. 2000). The lesions may also be due to the host response which is at first beneficial to help fight the disease but may induce an imbalance resulting in 
wasting, as in some cases of sepsis (Sharma \& Anker 2002). Pathogenic bacteria induce a dysfunction of some host proteinases resulting in the lysis of myofibrillar proteins (Hatzizisis et al. 2000, Saouda et al. 2001, Sun et al. 2003). A direct action of the bacteria on other tissue such as the nervous or the vasculatory system may induce muscular lesions as consequences. In the clostridial myonecrosis, bacteria induce a reduction of arteriolar flow impairing oxygen delivery and anoxic necrosis (Dastur \& Daver 1980, Stevens 2000). Finally, bacteria may have invaded and damaged the whole muscle and then migrated to other tissues during the time preceding the sampling of individuals for histological examination. Specific molecular tools (in situ hybridisation and GFP-expressing bacteria) are being developed to describe the infection route and eventual specific localisation and migrations of both strains.

Muscular lesions were not due to the inoculation method since they were also observed following bacterial injection into the pallial cavity. The observed lesions indicated a degeneration of the adductor muscle, which may explain the weakness of the oysters after experimental infection. The rounded granular structures described in the first type of alterations could have been bacteria globi as described by Lancaster et al. (1983) for Mycobacterium leprae. However, following Feulgen staining, these structures were found to be Feulgen negative, thus containing no DNA (not shown). The granular structures of the first and second types of alterations may be due to a large decrease in the myofibril density as observed in transmission electron microscopy. The membrane of the damaged muscular fibres seems to be intact, suggesting a phenomenon other than necrosis, where the first step is membrane disruption leading to influx of water and ions and thus to cell swelling and lysis. Cell alterations observed in the present work have been previously described in the literature; in some cases only one type of alteration was referred to (Abella et al. 2003), in others both were described and called coagulative necrosis, without any further descriptions of the mechanisms induced (Eldar et al. 1999). The 3 types of alterations may be interpreted as a succession of events: first a few muscular fibres were damaged, then the larger part of the adductor muscle displayed granular degenerating muscular fibres and finally, large parts of the organ contained very condensed muscular fibres.

Muscle alteration is one of the signs described in fish and mollusc vibriosis (McCarthy 1976, Bruno et al. 1986, Egidius 1987, Li et al. 1998). Furthermore, other pathogens were described as inducing muscular lesions in marine animals. For instance, the akoya-virus infection in the Japanese pearl oyster Pinctada fucata martensii induced necrosis, atrophy, swelling and vacuolisation of the muscle fibres of the adductor, foot, and pallial muscles (Miyazaki et al. 1999, Miyazaki et al. 2000). Co-infection of the giant freshwater prawn Macrobrachium rosenbergii by the yeast Metschnikowia bicuspidata and the bacteria Enterococcus faecium led to important edema and liquefactive necrosis in abdominal, pereipod and pleopod muscles (Chen et al. 2003). In several other bacterial models, muscular lesions seem to be either secondary lesions (Schaible et al. 1989, Ling et al. 2000) or consequences of an action of the pathogenic bacteria on other organs (Hund 2001), whereas in the $31+32$ infection model, no other organ appeared damaged.

A few individuals displayed massive infiltrations in the adductor muscle. However, it is noticeable that the vast majority of individuals displayed no infiltration associated with muscular lesions or degenerating cells, whereas inflammation is often observed at the site of infection either as a means of fighting the infectious agent or repairing the damaged tissue (Miyazaki et al. 1999, Neely et al. 2002). Some mollusc pathogens were described as inducing large increases in the circulating haemocytes densities (Oubella et al. 1993) and others were demonstrated to possess chemoattractants for oyster haemocytes (Cheng \& Howland 1979, Howland $\&$ Cheng 1982). The absence of inflammatory response may be due to different factors. Some bacterial pathogens mimic host structures to avoid this response (Moran et al. 1996), whereas others seem to produce toxins preventing inflammatory response $\left(\mathrm{O}^{\prime}\right.$ Brien \& Melville 2000). The presence of intense inflammation was only observed in some individuals and associated with condensed cells of the third type of alteration. Considering that condensed cells constitute the final stage of the disease, it may be hypothesised that infiltration plays a final role in clearing cell debris and healing the organ rather than being due to the direct action of the pathogenic bacteria (Ford et al. 1993). Experiments will be conducted with various sampling times in order to describe disease development.

The present study made it possible to describe bacterial localisation and muscular alterations following injection in the pallial cavity or in the adductor muscle of strains 31 and/or 32. However, no major difference was observed in light microscopy irrespective of whether the strains were inoculated individually or together. Thus, the strain specific virulence apparently does not induce differential structural changes in altered cells. Other approaches will be tested based on phenotypic features (production of toxic extracellular products) and on genomics (genomic subtraction).

Acknowledgements. The authors acknowledge Mr. Giraudeau for providing oysters and Prof. C. Tinsley for critically reading the manuscript. This study was carried out with financial assistance from the EU Community Reference Laboratory and the Région Poitou-Charentes. 


\section{LITERATURE CITED}

Abella BS, Kuchinic P, Hiraoka T, Howes DS (2003) Atraumatic clostridial myonecrosis: case report and literature review. J Emerg Med 24(4):401-405

Baticados MCL, Lavilla-Pitogo CR, De Cruz-Lacierda ER, la Pena LD, Junaz NA (1990) Studies on the chemical control of luminous bacteria Vibrio harveyi and V. splendidus isolated from diseased Penaeus monodon larvae and rearing water. Dis Aquat Org 9:133-139

Baumann P, Schubert RHW (1984) Family II Vibrionaceae Veron 1965, 5245 AL. In: Krieg NR, Holt JG (eds) Bergey's manual systematic of bacteriology. Williams \& Wilkins, Baltimore, MD, p 516-517

Baumann P, Baumann L, Bang SS, Woolkalis MJ (1980) Reevaluation of the taxonomy of Vibrio, Beneckea, and Photobacterium: abolition of the genus Beneckea. Curr Microbiol 4:127-132

Bruno DW, Hastings TS, Ellis AE (1986) Histopathology, bacteriology and experimental transmission of cold-water vibriosis in Atlantic salmon Salmo salar. Dis Aquat Org 1: 163-168

Cadavid D, O'Neill T, Schaefer H, Pachner AR (2000) Localization of Borrelia burgdorferi in the nervous system and other organs in a nonhuman primate model of lyme disease. Lab Invest 80(7):1043-1054

Castro D, Pujalte MJ, Lopez-Cortes L, Garay E, Borrego JJ (1992) Vibrio isolated from the cultured manila clam (Ruditapes philippinarum): numerical taxonomy and antibacterial activities. J Appl Microbiol 93:438-447

Chen SC, Chen TH, Wang PC, Chen YC, Huang JP, Lin YD, Chaung HC, Liaw LL (2003) Metschnikowia bicuspidata and Enterococcus faecium co-infection in the giant freshwater prawn Macrobrachium rosenbergii. Dis Aquat Org 55(2):161-167

Cheng TC, Howland KH (1979) Chemotactic attraction between haemocytes of the oyster, Crassostrea virginica, and bacteria. J Invertebr Pathol 33:204-210

Crosa JH, Brenner DJ, Falkow S (1973) Use of a single-strand specific nuclease for analysis of bacterial and plasmid deoxyribonucleic acid homo- and heteroduplexes. J Bacteriol 115:904-911

Dastur DK, Daver SM (1980) Striated muscle in four categories of leprosy. II. Fine structural changes. Int J Leprosy 48(2):149-158

Egidius E (1987) Vibriosis: pathogenicity and pathology. A review. Aquaculture 67:15-28

Eldar A, Perl S, Frelier PF, Bercovier H (1999) Red drum Sciaenops ocellatus mortalities associated with Streptococcus iniae infection. Dis Aquat Org 36(2):121-127

Farto R, Montes M, Perez MJ, Nieto TP, Larsen JL, Pedersen K (1999) Characterization by numerical taxonomy and ribotyping of Vibrio splendidus biovar I and Vibrio scophthalmi strains associated with turbot cultures. J Appl Microbiol 86:796-804

Farto R, Armada SP, Montes M, Guisande JA, Perez MJ, Nieto TP (2003) Vibrio lentus associated with diseased wild octopus (Octopus vulgaris). J Invertebr Pathol 83: 149-156

Ford SE, Kanaley SA, Littlewood DT (1993) Cellular responses of oysters infected with Haplosporidium nelsoni: changes in circulating and tissue-infiltrating haemocytes. J Invertebr Pathol 61:49-57

Friedman CS, Biggs W, Shields JD, Hedrick RP (2002) Transmission of withering syndrome in black abalone, Haliotis cracherodii leach. J Shellfish Res 21(2):817-824

Galtier N, Gouy M, Gautier C (1996) SEAVIEW and
PHYLO_WIN: two graphic tools for sequence alignment and molecular phylogeny. Comput Appl Biosci 12: $543-548$

Gascuel O (1997) BIONJ: an improved version of the NJ algorithm based on a simple model of sequence data. Mol Biol Evol 14:685-695

Gatesoupe FJ, Lambert C, Nicolas JL (1999) Pathogenicity of Vibrio splendidus strains associated with turbot larvae, Scophthalmus maximus. J Appl Microbiol 87:757-763

Gay M, Berthe FCJ, Le Roux F (2004) Screening of Vibrio isolates towards the development of an experimental infection model in the Pacific oyster, Crassostrea gigas. Dis Aquat Org 59:49-56

Grimont PAD (1984) Use of DNA reassociation in bacterial classification. Can J Microbiol 34:541-546

Grimont PAD, Popoff MY, Grimont F, Coynault C, Lemelin M (1980) Reproducibility and correlation study of three deoxyribonucleic acid hybridisation procedure. Curr Microbiol 4:325-330

Hatzizisis D, Gaitanaki C, Beis I (2000) Degradation of myofibrillar proteins by a calpain-like proteinase in the arm muscle of Octopus vulgaris. J Comp Physiol [B] 170(5-6): $447-456$

Howland KH, Cheng TC (1982) Identification of baterial chemoattractants for oyster (Crassostrea virginica) haemocytes. J Invertebr Pathol 39:123-132

Hund E (2001) Neurological complications of sepsis: critical illness polyneuropathy and myopathy. J Neurol 248(11): 929-934

Kelly MT, Dinuzzo A (1985) Uptake and clearance of Vibrio vulnificus from Gulf coast oysters (Crassostrea virginica). Appl Environ Microbiol 50(6):1548-1549

Lacoste A, Jalabert F, Malham S, Cueff A, Gélébart F, Cordevant C, Lange M, Poulet SA (2001) A Vibrio splendidus strain is associated with summer mortality of juvenile oysters Crassostrea gigas in the Bay of Morlaix (North Brittany, France). Dis Aquat Org 46:139-145

Lambert C, Nicolas JL, Cilia V (1999) Vibrio splendidusrelated strain isolated from brown deposit in scallop (Pecten maximus) cultured in Brittany (France). Bull Eur Asn Fish P 19:102-106

Lancaster RD, Hilson GR, McDougall AC, Colston MJ (1983) Mycobacterium leprae infection in nude mice: bacteriological and histological responses to primary infection and large inocula. Infect Immun 39(2):865-872

Le Roux F, Gay M, Lambert C, Waechter M, Poubalanne S, Chollet B, Nicolas JL, Berthe F (2002) Comparative analysis of Vibrio splendidus-related strains isolated during Crassostrea gigas mortality events. Aquat Living Resour 15:251-258

Le Roux F, Gay M, Lambert C, Nicolas JL, Gouy M, Berthe FCJ (2004) Phylogenetic study and identification of Vibrio splendidus related strains based on gyrB gene sequences. Dis Aquat Org 58:143-150

Li T, Ding M, Zhang J, Xiang J, Liu R (1998) Studies on the pustule disease of abalone (Haliotis discus hannai Ino) on the Dalian coast. J Shellfish Res 17:707-711

Ling SH, Wang XH, Xie L, Lim TM, Leung KY (2000) Use of green fluorescent protein (GFP) to study the invasion pathways of Edwardsiella tarda in in vivo and in vitro fish models. Microbiology 146(1):7-19

Lopez-Cortes L, Castro D, Navas JI, Borrego JJ (1999) Phagocytic and chemotactic responses of manila and carpet shell clam haemocytes against Vibrio tapetis, the causative agent of brown ring disease. Fish Shellfish Immun 9(7): 543-555

Macian MC, Ludwig W, Aznar R, Grimont PA, Schleifer KH 
Garay E, Pujalte MJ (2001) Vibrio lentus sp. nov., isolated from Mediterranean oysters. Int J Syst Evol Microbiol 51: 1449-1456

Martin Y, Bonnefont JL, Chancerelle L (2002) Gorgonians mass mortality during the 1999 late summer in French Mediterranean coastal waters: the bacterial hypothesis. Water Res 36:779-782

McCarthy DH (1976) Vibrio disease in eels. J Fish Biol 8: $317-320$

Miyazaki T, Goto K, Kobayashi T, Kageyama T, Miyata M (1999) Mass mortalities associated with a virus disease in Japanese pearl oysters Pinctada fucata martensii. Dis Aquat Org 37(1):1-12

Miyazaki T, Nozawa N, Kobayashi T (2000) Clinical trial results on the use of a recombinant feline interferonomega to protect Japanese pearl oysters Pinctada fucata martensii from akoya-virus infection. Dis Aquat Org 43(1): $15-26$

Moore JD, Cherr GN, Friedman CS (2001) Detection of 'Candidatus Xenohaliotis californiensis' (Rickettsiales-like prokaryote) inclusions in tissue squashes of abalone (Haliotis spp.) gastrointestinal epithelium using a nucleic acid fluorochrome. Dis Aquat Org 46(2):147-152

Moran AP, Prendergast MM, Appelmelk BJ (1996) Molecular mimicry of host structures by bacterial lipopolysaccharides and its contribution to disease. FEMS Immunol Med Microbiol 16(2):105-115

Myhr E, Larsen JL, Lillehaug A, Gudding R, Heum M, Hastein T (1991) Characterization of Vibrio anguillarum and closely related species isolated from farmed fish in Norway. Appl Environ Microb 57:2750-2757

Myrand B, Guderley H, Himmelman JH (2000) Reproduction and summer mortality of blue mussels Mytilus edulis in the Magdalene Islands, Southern Gulf of St. Lawrence. Mar Ecol Prog Ser 197:193-207

Nealson KH, Wimpee B, Wimpee C (1993) Identification of Vibrio splendidus as a member of the planktonic luminous bacteria from Persian Gulf and Kuwait region with LuxA probes. Appl Environ Microb 59:2684-2689

Neely MN, Pfeifer JD, Caparon M (2002) Streptococcuszebrafish model of bacterial pathogenesis. Infect Immun 70(7):3904-3914

Nicolas JL, Corre S, Gauthier G, Robert R, Ansquer D (1996) Bacterial problems associated with scallop Pecten maximus larval culture. Dis Aquat Org 27:67-76

Nordmo R, Ramstad A (1999) Variables affecting the challenge presure of Aeromonas salmonicida and Vibrio salmonicida in Atlantic salmon (Salmo salar L.). Aquaculture 171:1-12

O'Brien DK, Melville SB (2000) The anaerobic pathogen Clostridium perfringens can escape the phagosome of macrophages under aerobic conditions. Cell Microbiol 2(6):505-519

Ottaviani D, Bacchiocchi I, Masini L, Carraturo A, Russo GL, Giammarioli M, Sbaraglia G (2001) Correlation between medium acidification and pathogenicity in environmental halophilic non-cholera vibrios. Lett Appl Microbiol 33: 61-64

Oubella R, Maes P, Paillard C, Auffret M (1993) Experimentally induced variation in haemocyte density for Ruditapes

Editorial responsibility: David Bruno,

Aberdeen, UK philippinarum and $R$. decussatus (Mollusca, Bivalvia). Dis Aquat Org 15:193-197

Paillard C, Maes P (1990) Etiologie de la maladie de l'anneau brun chez Tapes philippinarum: pathogénicité d'un Vibrio sp. CR Acad Sci Paris 310:15-20

Perdue JA, Beattie JH, Chew KK (1981) Some relationships between gametogenic cycle and summer mortality phenomenon in the Pacific oyster C. gigas in the Washington state. J Shellfish Res 1:9-16

Renault T, Cochennec N (1995) Chlamydia-like organisms in ctenidia and mantle cells of the Japanese oyster Crassostrea gigas from the French Atlantic coast. Dis Aquat Org 23(2):153-159

Saouda M, Wu W, Conran P, Boyle MD (2001) Streptococcal pyrogenic exotoxin B enhances tissue damage initiated by other Streptococcus pyogenes products. J Infect Dis 184(6):723-731

Schaible UE, Kramer MD, Justus CW, Museteanu C, Simon MM (1989) Demonstration of antigen-specific T cells and histopathological alterations in mice experimentally inoculated with Borrelia burgdorferi. Infect Immun 57(1): $41-47$

Sharma R, Anker SD (2002) Cytokines, apoptosis and cachexia: the potential for TNF antagonism. Int J Cardiol 85(1): 161-171

Soletchnik P, Razet D, Geairon P, Faury N, Goulletquer P (1997) Ecophysiologie de la maturation sexuelle et de la ponte de l'huître creuse C. gigas: réponses métaboliques (respiration) et alimentaires (filtration, absorption) en fonction des différents stades de maturation. Aquat Living Resour 10:177-185

Stackebrandt E, Frederiksen W, Garrity GM, Grimont PAD and 9 others (2002) Report of the Ad Hoc committee for the re-evaluation of the species definition in bacteriology. Int J Syst Evol Microb 52:1043-1047

Stevens DL (2000) The pathogenesis of clostridial myonecrosis. Int J Med Microbiol 290(4-5):497-502

Sugumar G, Nakai T, Hirata Y, Matsubara D, Muroga K (1998) Vibrio splendidus biovar II as the causative agent of bacillary necrosis of Japanese oyster Crassostrea gigas larvae. Dis Aquat Org 33:111-118

Sun X, Mammen JM, Tian X (2003) Sepsis induces the transcription of the glucocorticoid receptor in skeletal muscle cells. Clin Sci 105(3):383-391

Thompson FL, Hoste B, Vandemeulebroecke K, Swings J (2001) Genomic diversity amongst Vibrio isolates from different sources determined by fluorescent amplified fragment length polymorphism. Syst Appl Microbiol 24: 520-538

Thompson FL, Thompson CC, Li Y, Gomez-Gil B, Vandenberghe J, Hoste B, Swings J (2003a) Vibrio kanaloae sp. nov., Vibrio pomeroyi sp. nov. and Vibrio chagasii sp. nov., from sea water and marine animals. Int J Syst Evol Microb 53:753-759

Thompson FL, Thompson CC, Swings J (2003b) Vibrio tasmaniensis sp. nov., isolated from Atlantic salmon (Salmo salar L.). Syst Appl Microbiol 26:65-69

Waechter M, Le Roux F, Nicolas JL, Marissal E, Berthe F (2002) Characterisation of Crassostrea gigas spat pathogenic bacteria. CR Biologies 325:231-238

Submitted: January 30, 2004; Accepted: June 7, 2004

Proofs received from author(s): October 20, 2004 